Open Access

\title{
Long contiguous stretches of homozygosity spanning shortly the imprinted loci are associated with intellectual disability, autism and/or epilepsy
}

Ivan Y. Iourov ${ }^{1,2,3^{*}}$, Svetlana G. Vorsanova ${ }^{1,2}$, Sergei A. Korostelev ${ }^{4}$, Maria A. Zelenova ${ }^{1,2}$ and Yuri B. Yurov ${ }^{1,2}$

\begin{abstract}
Background: Long contiguous stretches of homozygosity (LCSH) (regions/runs of homozygosity) are repeatedly detected by single-nucleotide polymorphism (SNP) chromosomal microarrays. Providing important clues regarding parental relatedness (consanguinity), uniparental disomy, chromosomal recombination or rearrangements, LCSH are rarely considered as a possible epigenetic cause of neurodevelopmental disorders. Additionally, despite being relevant to imprinting, LCSH at imprinted loci have not been truly addressed in terms of pathogenicity. In this study, we examined LCSH in children with unexplained intellectual disability, autism, congenital malformations and/or epilepsy focusing on chromosomal regions which harbor imprinted disease genes.
\end{abstract}

Results: Out of 267 cases, 14 (5.2 \%) were found to have LCSH at imprinted loci associated with a clinical outcome. There were 5 cases of LCSH at 15p11.2, 4 cases of LCSH at 7q31.2, 3 cases of LCSH at 11p15.5, and 2 cases of LCSH at 7q21.3. Apart from a case of LCSH at 7q31.33q32.3 ( 4 Mb in size), all causative LCSH were 1-1.5 Mb in size. Clinically, these cases were characterized by a weak resemblance to corresponding imprinting diseases (i.e., Silver-Russell, Beckwith-Wiedemann, and Prader-Willi/Angelman syndromes), exhibiting distinctive intellectual disability, autistic behavior, developmental delay, seizures and/or facial dysmorphisms. Parental consanguinity was detected in 8 cases $(3 \%)$, and these cases did not exhibit LCSH at imprinted loci.

Conclusions: This study demonstrates that shorter LCSH at chromosomes 7q21.3, 7q31.2, 11p15.5, and 15 p11.2 occur with a frequency of about $5 \%$ in the children with intellectual disability, autism, congenital malformations and/or epilepsy. Consequently, this type of epigenetic mutations appears to be the most common one among children with neurodevelopmental diseases. Finally, since LCSH less than 2.5-10 Mb in size are generally ignored in diagnostic SNP microarray studies, one can conclude that an important epigenetic cause of intellectual disability, autism or epilepsy is actually overlooked.

Keywords: Long continuous stretches of homozygosity, Intellectual disability, Congenital anomalies, Autism, Epilepsy, Epigenetics, Bioinformatics

\footnotetext{
* Correspondence: ivan.iourov@gmail.com

${ }^{1}$ Mental Health Research Center, 117152 Moscow, Russia

${ }^{2}$ Separated Structural Unit "Clinical Research Institute of Pediatrics", Russian

National Research Medical University named after N.I. Pirogov, Ministry of

Health of Russian Federation, 125412 Moscow, Russia

Full list of author information is available at the end of the article
} 


\section{Background}

The genetic causes of neurodevelopmental disorders include almost all types of genomic variations (mainly, chromosomal rearrangements (microscopic and submicroscopic), copy number variations (CNV) and single gene mutations) [1-7]. Additionally, epigenetic alterations due to genomic variations affecting genes involved in epigenomic regulation and uniparental disomy resulting from chromosomal or segmental homozygosity (HMZ) are shown to contribute to the etiology of neurodevelopmental diseases [8-11]. However, epigenomic variations and instability have been significantly less investigated in terms of the causative role for these diseases than deserved $[10,11]$. Moreover, genome- and epigenome-based analysis of brain cells suggests that epigenetic changes are likely an underappreciated source of neuronal diversity and neurodevelopmental diseases [12]. Accordingly, one can hypothesize that overlooked epigenomic variations might be involved in the pathogenesis of neurological and psychiatric diseases.

Probably the commonest type of epigenomic variations in humans is long contiguous stretches of homozygosity (LCSH) (also known as regions/runs of homozygosity and losses of heterozygosity) defined as CNV neutral chromosomal segments featured by allelic HMZ [13-15]. LCSH over $1 \mathrm{Mb}$ are always observed during genome-wide analyses by single-nucleotide polymorphism (SNP) chromosomal microarrays [16-19]. The presence of LCSH can be indicative for parental consanguinity, uniparental disomy, or HMZ for single gene recessive mutations [19-21]. Furthermore, LCHS are helpful for uncovering the genetic basis for complex traits [22] and locus-specific deleterious genomic variation [23]. Taking into account the epigenetic contribution to brain development and plasticity as well as genetic-environmental interactions in neuropsychiatric diseases, epigenomic variability was suggested to be a mechanism for neurodevelopmental disorders [24, 25]. Recently, several studies have addressed LCSH in brain diseases. However, these yielded conflicting results [26-28]. Actually, the only more-or-less confirmed association between LCSH occurrence and neurodevelopmental diseases (intellectual disability (ID) and autism) is related to excess of LCSH encompassing recessive disease genes $[19,29]$. Surprisingly, imprinted gene loci were not considered as a target for studying LCSH in neurodevelopmental disorders. Since classical imprinting syndromes, i. e. Angelman syndrome (AS), Beckwith-Wiedemann syndrome (BWS), Prader-Willi syndrome (PWS) and SilverRussell syndrome (SRS), are associated with ID, autistic behavior, developmental delay, and seizures [30, 31], we hypothesize that LCSH at these disease loci may result in a similar neurological or behavioral phenotype.

In this study, LCSH were evaluated in a cohort of children with idiopathic intellectual disability, autism, congenital malformations and/or epilepsy by SNP chromosomal microarray with a resolution of HMZ stretch detection reaching a minimum of $1 \mathrm{Mb}$ in size. An original bioinformatics approach to the prioritization of genes and genome/epigenome variations was used to assess pathogenic value of $\mathrm{CNV}$ and $\mathrm{LCSH}$.

\section{Results}

The presence of LCSH was observed in all cases studied. Causative chromosome abnormalities, $\mathrm{CNV}$ and intragenic (exonic) CNV detected by SNP microarray technique were excluded from further analysis. Apart from individuals, who were the descendants of close consanguinity marriages, the amount of LCSH per patient varied between 63 and 132. Eight individuals (3\%) were descendants of close consanguinity marriages. Parental consanguinity was determined according to a methodology of a previous study by Fan et al. [32] and genealogic analysis. In these patients, LCSH have not spanned the loci of imprinted genes strongly associated with recognizable syndromes. A patient, who is a descendant of consanguinity mating, exhibited LCSH at 7p12, containing an imprinted gene GRB10. Since the involvement of GRB10 in SRS is questionable [33], we have excluded this case from further analysis.

LCSH at imprinted loci previously described as those of imprinting syndromes [34-36] were found in 14 cases (5.2\%). These were 2 cases of LCSH at 7q21.3 (SRS), 4 cases of LCSH at 7q31.2, 3 (SRS) (Fig. 1), LCSH at 11p15.5 (SRS/BWS) (Fig. 2), and LCSH at 15p11.2 (AS/ PWS) (Fig. 3). Molecularly, LHCS spanned the loci containing imprinted genes checked by the GENEIMPRINT database (http://www.geneimprint.com/site/genes-byspecies.Homo+sapiens). Apart from a case of LCSH at $7 \mathrm{q} 31.33 \mathrm{q} 32.3$ ( $4.3 \mathrm{Mb}$ in size), the remaining LHCS spanned DNA sequences varied from 1 to $1.6 \mathrm{Mb}$. No correlation with the size of LCSH and disease's phenotype was observed. The size of LCSH was indicative for excluding whole-chromosome uniparental disomy as the mechanism for phenotypic manifestations in these cases. Table 1 summarizes data on molecular, chromosomal and clinical features of LCSH at the imprinted chromosomal regions.

\section{Discussion}

Epigenomic variations and instability are known to be associated with human diseases $[8-12,21,24,30]$. Here, a primary imprinting defect (according to previous classification of imprinting defects [37]) is described. Along with chromosomal abnormalities and CNV (germline and somatic) [1-7, 38-40], these epigenetic mutations can be considered as a common cause of neurodevelopmental diseases. There are no known epigenetic/epigenomic alterations detectable as 


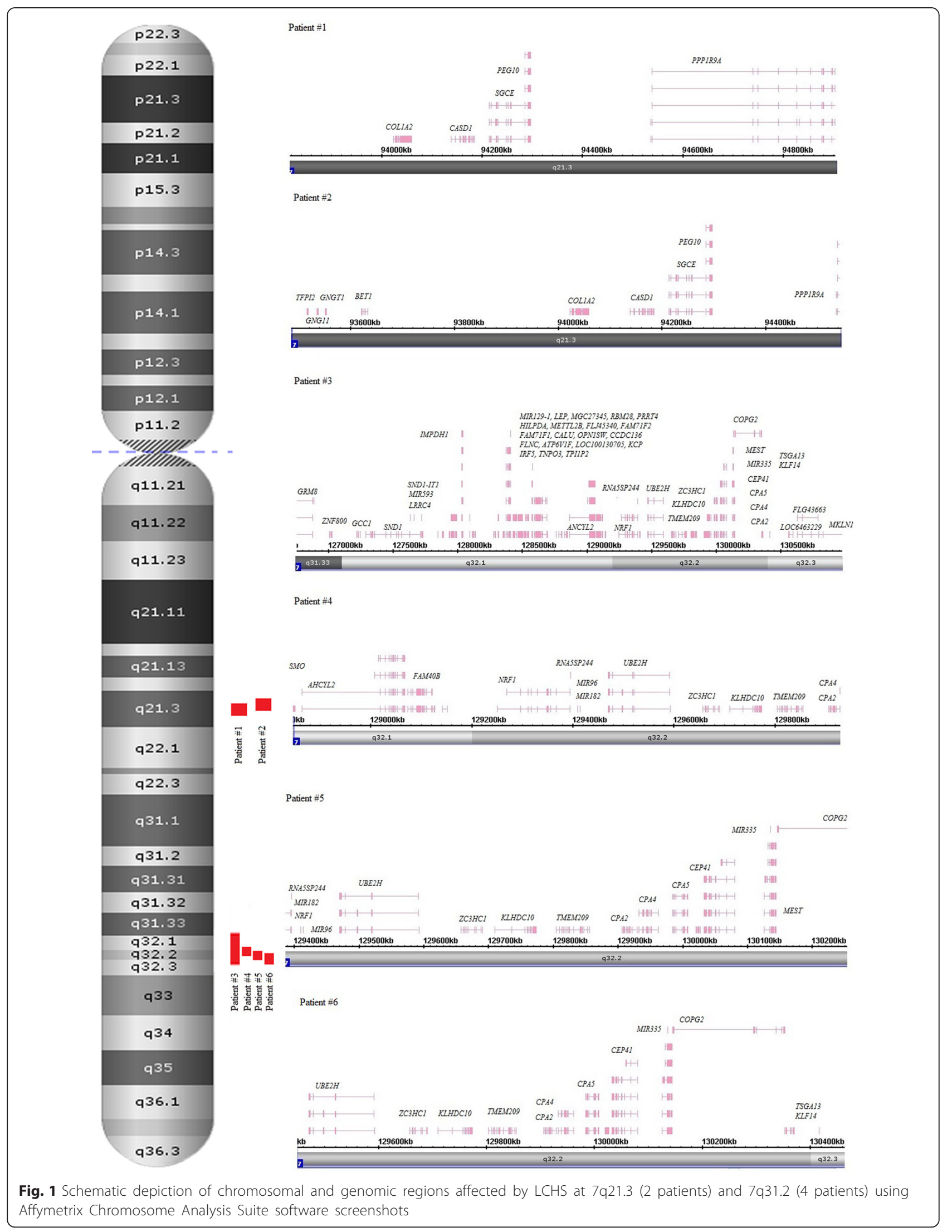




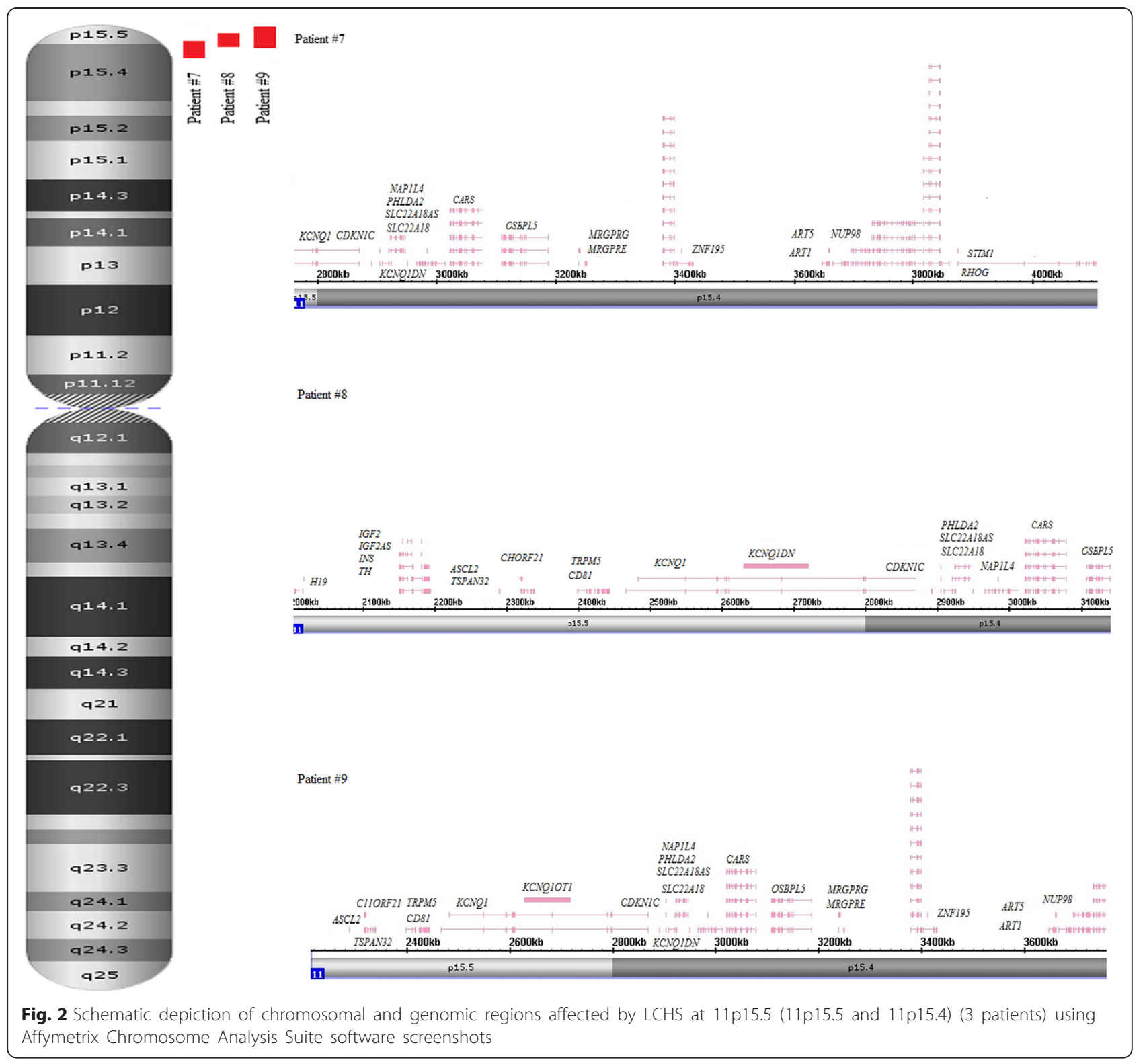

common as LCSH at imprinted loci that can be considered as a causative for ID, autism or epilepsy. It is noteworthy, that LCSH are detectable by SNP chromosomal microarrays only $[18,20,21,32,41,42]$. Although imprinting defects similar to LCSH can be also detected by molecular genetic approaches (methyl-sensitive polymerase chain reaction, bisulfite sequencing etc.) $[36,41,43]$, these techniques are poorly effective for the detection because of their targeted nature. SNP chromosomal microarrays may lead to a $5 \%$ improvement in etiological yield by uncovering LCSH at imprinted loci.

Clinically, 14 cases of LCSH spanning shortly the imprinted loci weakly resembled SRS, BWS, AS or PWS [10, 34-36, 43, 44]. Additional phenotypic features have been observed, as well (Table 1). In total, phenotypic manifestations in these cases have not allowed attributing them to a specific imprinting syndrome providing speculations about causative relationship between unexplained ID, autism and epilepsy and LCSH at imprinted loci.

Since LCSH were observed in all the individuals of the cohort, we have compared our results with previous studies of clinical and unaffected populations [13-23]. Identical LCSH in unrelated individuals were found to be confined to specific regions (i.e., $3 \mathrm{p} 21$ and 16p11.2p11.1). These were detected in the majority of patients. Consequently, we concluded that these LCSH are the result of a technological drawback. However, specific organization of these genomic loci 


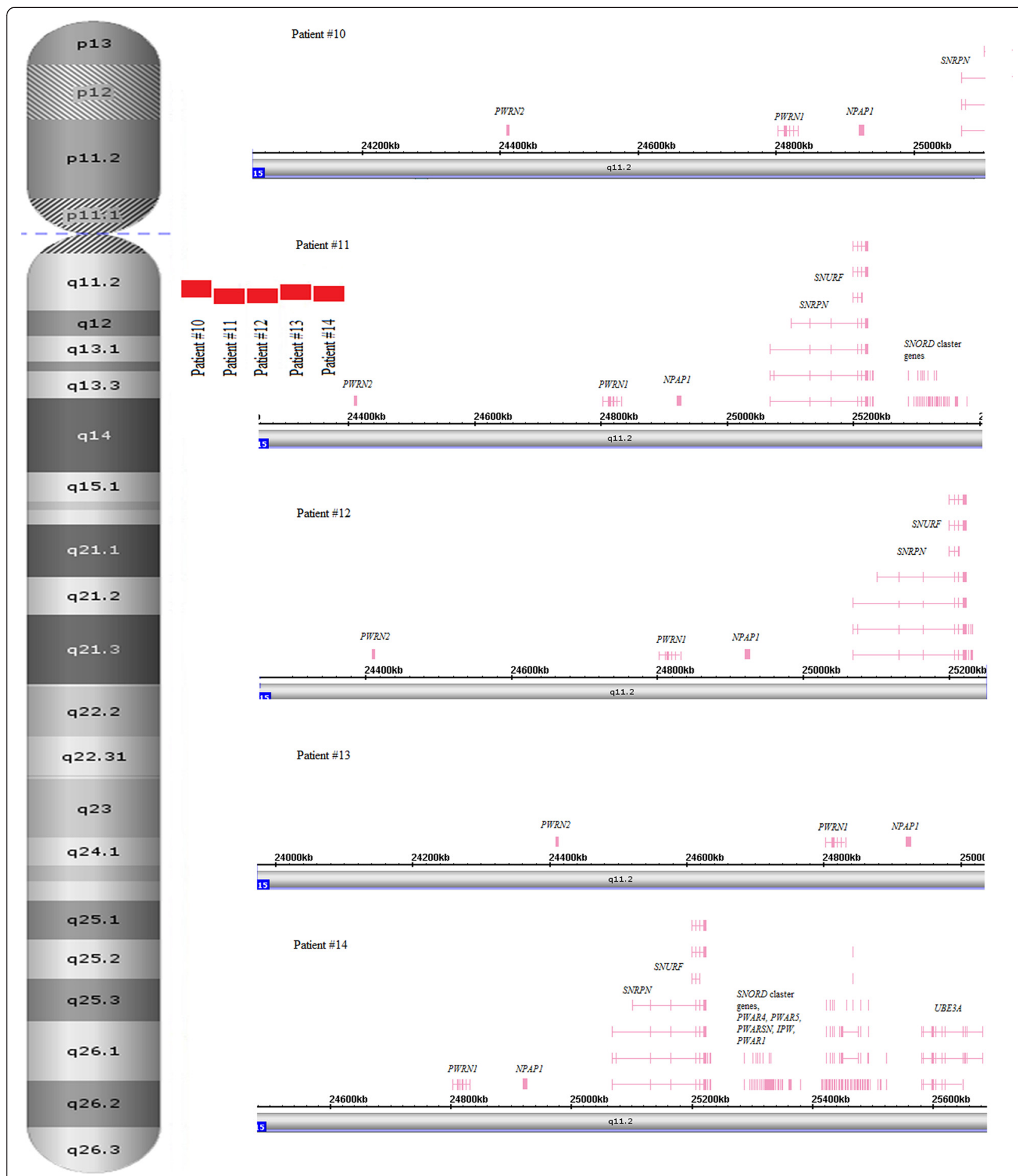

Fig. 3 Schematic depiction of chromosomal and genomic regions affected by LCHS at 15q11.2 (5 patients) using Affymetrix Chromosome Analysis Suite software screenshots

can manifest as LCSH during SNP chromosomal microarray analysis. In the available literature, $7 \mathrm{q} 21.3$, $7 \mathrm{q} 31.2,11 \mathrm{p} 15.5$, and $15 \mathrm{p} 11.2$ genomic loci were not described as consistently affected by LCSH [13-20].
Although Wang et al. 2015 [21] have reported large LCSH to affect $11 \mathrm{p}$ and $15 \mathrm{q}$, these occasional cases are likely to represent rare cases of uniparental disomy associated with corresponding imprinting disorders. 
Table 1 Summary of LCSH, associated clinical findings, and imprinted genes

\begin{tabular}{|c|c|c|c|c|c|}
\hline $\begin{array}{l}\text { Case } \\
\# \\
\end{array}$ & $\begin{array}{l}\text { Chromosomal } \\
\text { region }\end{array}$ & Age & Clinical features & Size, kb & Genes (imprinted) \\
\hline 1 & $7 q 21.3$ & 5 years & Developmental delay, autistic behavior, hyperactivity & 1098 & SGCE, PEG10 PPP1R9A \\
\hline 2 & $7 q 21.3$ & 11 years & Intellectual disability, developmental delay & 1062 & SGCE, PEG10, PPP1R9A, TFPI2 \\
\hline 3 & $7 q 31.33 q 32.3$ & 2 years & $\begin{array}{l}\text { Intellectual disability, developmental delay, } \\
\text { microcephaly, seizures, facial dysmorphisms, } \\
\text { muscular hypotonia }\end{array}$ & 4257 & KLF14, MEST, COPG2, MESTIT1, CPA4 \\
\hline 4 & $7 q 32.1 q 32.2$ & $\begin{array}{l}2 \text { years } \\
7 \text { months }\end{array}$ & $\begin{array}{l}\text { Intellectual disability, developmental delay, } \\
\text { microcephaly, seizures, facial dysmorphisms }\end{array}$ & 1089 & CPA4 \\
\hline 5 & $7 q 32.2$ & 3 years & $\begin{array}{l}\text { Intellectual disability, developmental delay, facial } \\
\text { dysmorphisms }\end{array}$ & 1033 & CPA4, MESTIT1, MEST, COPG2 \\
\hline 6 & $7 q 32.2$ & 15 years & $\begin{array}{l}\text { Intellectual disability, developmental delay, } \\
\text { congenital heart defect }\end{array}$ & 1020 & KLF14, MEST, COPG2, MESTIT1, CPA4 \\
\hline 7 & $11 \mathrm{p} 15.5 \mathrm{p} 15.4$ & 5 years & $\begin{array}{l}\text { Intellectual disability, autistic behavior, microcephaly, } \\
\text { seizures, facial dysmorphisms, somatic overgrowth }\end{array}$ & 1360 & $\begin{array}{l}\text { CDKN1C, KCNQ1DN, KCNQ1, SLC22A18AS, } \\
\text { SLC22A18, PHLDA2, NAP1L4, OSBPL5, }\end{array}$ \\
\hline 8 & $11 \mathrm{p} 15.5 \mathrm{p} 15.4$ & 10 years & $\begin{array}{l}\text { Developmental delay, autistic behavior, facial } \\
\text { dysmorphisms, somatic overgrowth }\end{array}$ & 1147 & $\begin{array}{l}\text { IGF2, H19, CDKN1C, KCNQ1DN, KCNQ1, SLC22A18, } \\
\text { PHLDA2, NAP1L4, OSBPL5, IGF2AS, INS, TH, ASCL2, } \\
\text { TSPAN32, CD81, TSSC4, TRPM5, KCNQ1OT1, } \\
\text { SLC22A18AS }\end{array}$ \\
\hline 9 & $11 p 15.5 p 15.4$ & 4 years & $\begin{array}{l}\text { Intellectual disability, developmental delay, } \\
\text { macrocephaly, feeding difficulty, umbilical hernia, } \\
\text { hepatomegaly, undescended testis, facial } \\
\text { dysmorphisms, short neck }\end{array}$ & 1554 & $\begin{array}{l}\text { CDKN1C, KCNQ1, KCNQ1OT1, ASCL, TSPAN32, } \\
\text { CD81, TSSC4, TRPM5, SLC22A18AS, SLC22A18, } \\
\text { PHLDA2 NAP1L4, OSBPL5 }\end{array}$ \\
\hline 10 & $15 q 11.2$ & $\begin{array}{l}2 \text { years } \\
10 \text { months }\end{array}$ & $\begin{array}{l}\text { Intellectual disability, developmental delay, feeding } \\
\text { difficulty, facial dysmorphisms }\end{array}$ & 1068 & NPAP1, SNRPN \\
\hline 11 & $15 q 11.2$ & 4 years & $\begin{array}{l}\text { Intellectual disability, developmental delay, } \\
\text { hyperactivity, facial dysmorphisms, seizures }\end{array}$ & 1158 & SNRPN, PAR1, IPW, PAR5, \\
\hline 12 & $15 q 11.2$ & 5 years & $\begin{array}{l}\text { Developmental delay, autistic behavior, seizures, } \\
\text { facial dysmorphisms }\end{array}$ & 1002 & NPAP1, SNRPN \\
\hline 13 & $15 q 11.2$ & 5 years & $\begin{array}{l}\text { Developmental delay, autistic behavior, fetal cerebral } \\
\text { ventriculomegaly, facial dysmorphisms }\end{array}$ & 1067 & NPAP1 \\
\hline 14 & $15 q 11.2$ & 18 years & Intellectual disability, personality disorder & 1224 & $\begin{array}{l}\text { NPAP1, SNRPN, SNURF, SNORD107, SNORD108, } \\
\text { SNORD109B, SNORD109A UBE3A }\end{array}$ \\
\hline
\end{tabular}

Accordingly, these epigenomic mutations are unlikely to represent the same short LCSH reported in the present study.

Mechanisms and consequences of LCSH are poorly understood [13-15, 45]. Accordingly, the interpretation of these epigenetic mutations can represent a challenge. To solve the problem in silico, one can apply a variety of bioinformatic approaches to gene prioritization, which are known to be effective for uncovering functional significance of genomic and epigenomic variations [40, 46, 47]. Molecular testing for AS and PWS performed previously (fluorescence in situ hybridization-based and methylation analyses) [48] was not able to uncover these epigenetic mutations. Therefore, it is important to note that alternative empirical methods giving a solution to this problem do not currently exist.

\section{Conclusions}

This molecular cytogenetic and bioinformatic study shows for the first time that LCSH of $1-1.6 \mathrm{Mb}$ in size at imprinted chromosomal regions (7q21.3, 7q31.2;
$11 \mathrm{p} 15.5$; and $15 \mathrm{p} 11.2)$ are relatively frequent ( 5 \%) among the children with intellectual disability, autism, congenital malformations and/or epilepsy. Thus, these epigenetic mutations appear to be common in neurodevelopmental diseases. Hence, to increase the diagnostic yield of SNP chromosomal microarrays, an additional consideration of shorter LCSH is warranted in children with intellectual disability, autism, congenital malformations and/or epilepsy.

\section{Methods \\ Patients}

Cases $(n=267)$ included in this study are a part of the Russian cohort of children with intellectual disability, autism, epilepsy and congenital anomalies partially described previously [49-51]. Written informed consent was obtained from at least one of the patients' parents.

\section{SNP chromosomal microarray}

$\mathrm{CNV}$ and LCSH were analyzed by CytoScan HD Arrays (Affymetrix, Santa Clara, CA) consisting of about 2.7 
million markers for $\mathrm{CNV}$ evaluation and about 750,000 SNPs for LCSH analysis. The laboratory procedures have been previously described in detail $[17,18,21,51,52]$. $\mathrm{CNV}$ and LCSH were visualized by the Affymetrix Chromosome Analysis Suite software (ChAS analysis files for CytoScan ${ }^{\circ}$ HD Array version NA32.3). Genomic localization was defined using NCBI Build GRCh37/hg19 reference sequence. Imprinted genes were checked against the Geneimprint database (http://www.geneimprint.com).

\section{Bioinformatics}

Bioinformatic analyses were performed using an original approach to gene and $\mathrm{CNV}$ prioritization as described in our earlier papers $[46,51,53]$. This procedure was performed to exclude the phenotypic effect of $\mathrm{CNV}$ and to confirm clinical relevance of LCSH. Briefly, the prioritization was performed using ontology-based gene filtering/ranking and fusion of data acquired from clinical, genomic, epigenetic, proteomic, and metabolomic databases as well as interactomic software.

\section{Abbreviations}

AS: Angelman syndrome; BWS: Beckwith-Wiedemann syndrome; CNV: Copy number variations; HMZ: Homozygosity; ID: Intellectual disability; LCSH: Long contiguous stretches of homozygosity; PWS: Prader-Willi syndrome; SRS: Silver-Russell syndrome; SNP: Single-nucleotide polymorphism.

\section{Competing interests}

The authors declare that they have no competing interests.

\section{Authors' contributions}

IYI, SGV and YBY conceived the research, wrote the manuscript, and obtained the funding. IYI, SGV, SAK and YBY designed the study. IYI and SAK performed the experiments. IYI and MAZ performed bioinformatic analyses. All authors have read and approved the final manuscript.

\section{Acknowledgments}

We thank Oxana S. Kurinnaia and Kirill S. Vasin for technical assistance. The study was supported by the Russian Science Foundation (project \#14-15-00411).

\section{Author details \\ ${ }^{1}$ Mental Health Research Center, 117152 Moscow, Russia. ${ }^{2}$ Separated Structural Unit "Clinical Research Institute of Pediatrics", Russian National Research Medical University named after N.I. Pirogov, Ministry of Health of Russian Federation, 125412 Moscow, Russia. ${ }^{3}$ Department of Medical Genetics, Russian Medical Academy of Postgraduate Education, 123995 Moscow, Russia. ${ }^{4}$ Research Centre for Medical Genetics, 115478 Moscow, Russia.}

Received: 14 August 2015 Accepted: 27 September 2015

Published online: 15 October 2015

\section{References}

1. Ellison JW, Rosenfeld JA, Shaffer LG. Genetic basis of intellectual disability. Annu Rev Med. 2013;64:441-50.

2. Huguet $G$, Ey E, Bourgeron T. The genetic landscapes of autism spectrum disorders. Annu Rev Genomics Hum Genet. 2013;14:191-213.

3. lourov IY, Vorsanova SG, Yurov YB. Molecular cytogenetics and cytogenomics of brain diseases. Curr Genomics. 2008;9(7):452-65.

4. Mefford HC, Batshaw ML, Hoffman EP. Genomics, intellectual disability, and autism. N Engl J Med. 2012;366(8):733-43.

5. Rauch A, Wieczorek D, Graf E, Wieland T, Endele S, Schwarzmayr T, et al. Range of genetic mutations associated with severe non-syndromic sporadic intellectual disability: an exome sequencing study. Lancet. 2012;380(9854):1674-82.
6. Srivastava AK, Schwartz CE. Intellectual disability and autism spectrum disorders: causal genes and molecular mechanisms. Neurosci Biobehav Rev. 2014;46(Pt 2):161-74.

7. Vorsanova SG, Yurov YB, Soloviev IV, lourov IY. Molecular cytogenetic diagnosis and somatic genome variations. Curr Genomics. 2010;11(6):440-6.

8. Egger G, Liang G, Aparicio A, Jones PA. Epigenetics in human disease and prospects for epigenetic therapy. Nature. 2004;429(6990):457-63.

9. Liehr T. Cytogenetic contribution to uniparental disomy (UPD). Mol Cytogenet. 2010;3:8.

10. Rangasamy S, D'Mello SR, Narayanan V. Epigenetics, autism spectrum, and neurodevelopmental disorders. Neurotherapeutics. 2013;10(4):742-56.

11. Smith $C L$, Bolton A, Nguyen G. Genomic and epigenomic instability, fragile sites, schizophrenia and autism. Curr Genomics. 2010;11(6):447-69.

12. Iourov IY, Vorsanova SG, Yurov YB. Single cell genomics of the brain: focus on neuronal diversity and neuropsychiatric diseases. Curr Genomics. 2012;13(6):477-88.

13. Li LH, Ho SF, Chen CH, Wei CY, Wong WC, Li LY, et al. Long contiguous stretches of homozygosity in the human genome. Hum Mutat. 2006;27(11):1115-21.

14. McQuillan R, Leutenegger AL, Abdel-Rahman R, Franklin CS, Pericic M, Barac-Lauc L, et al. Runs of homozygosity in European populations. Am J Hum Genet. 2008;83(3):359-72.

15. Kirin M, McQuillan R, Franklin CS, Campbell H, McKeigue PM, Wilson JF. Genomic runs of homozygosity record population history and consanguinity. PLoS One. 2010;5(11), e13996.

16. Bruno DL, White SM, Ganesamoorthy D, Burgess T, Butler K, Corrie S, et al. Pathogenic aberrations revealed exclusively by single nucleotide polymorphism (SNP) genotyping data in 5000 samples tested by molecular karyotyping. J Med Genet. 2011;48(12):831-9.

17. Lin PI, Kuo PH, Chen CH, Wu JY, Gau SS, Wu YY, et al. Runs of homozygosity associated with speech delay in autism in a Taiwanese Han population: evidence for the recessive model. PLoS One. 2013;8(8), e72056.

18. D'Amours G, Langlois M, Mathonnet G, Fetni R, Nizard S, Srour M, et al. SNP arrays: comparing diagnostic yields for four platforms in children with developmental delay. BMC Med Genomics. 2014;7:70.

19. Gandin I, Faletra F, Faletra F, Carella M, Pecile V, Ferrero GB, et al. Excess of runs of homozygosity is associated with severe cognitive impairment in intellectual disability. Genet Med. 2015;17(5):396-9.

20. Grote L, Myers M, Lovell A, Saal H, Lipscomb SK. Variability in laboratory reporting practices for regions of homozygosity indicating parental relatedness as identified by SNP microarray testing. Genet Med. 2012;14(12):971-6.

21. Wang JC, Ross L, Mahon LW, Owen R, Hemmat M, Wang BT, et al. Regions of homozygosity identified by oligonucleotide SNP arrays: evaluating the incidence and clinical utility. Eur J Hum Genet. 2015;23(5):663-71.

22. Ku CS, Naidoo N, Teo SM, Pawitan Y. Regions of homozygosity and their impact on complex diseases and traits. Hum Genet. 2011;129(1):1-15.

23. Szpiech ZA, Xu J, Pemberton TJ, Peng W, Zöllner S, Rosenberg NA, et al. Long runs of homozygosity are enriched for deleterious variation. Am J Hum Genet. 2013;93(1):90-102.

24. Fagiolini M, Jensen CL, Champagne FA. Epigenetic influences on brain development and plasticity. Curr Opin Neurobiol. 2009;19(2):207-12.

25. lourov IY, Vorsanova SG, Yurov YB. Somatic cell genomics of brain disorders: a new opportunity to clarify genetic-environmental interactions. Cytogenet Genome Res. 2013;139(3):181-8.

26. Heron EA, Cormican P, Donohoe G, O'Neill FA, Kendler KS, Riley BP, et al. No evidence that runs of homozygosity are associated with schizophrenia in an Irish genome-wide association dataset. Schizophr Res. 2014;154(1-3):79-82.

27. Melhem NM, Lu C, Dresbold C, Middleton FA, Klei L, Wood S, et al. Characterizing runs of homozygosity and their impact on risk for psychosis in a population isolate. Am J Med Genet B Neuropsychiatr Genet. 2014; 165B(6):521-30.

28. Power RA, Keller MC, Ripke S, Abdellaoui A, Wray NR, Sullivan PF, et al. A recessive genetic model and runs of homozygosity in major depressive disorder. Am J Med Genet B Neuropsychiatr Genet. 2014;165B(2):157-66.

29. Gamsiz ED, Viscidi EW, Frederick AM, Nagpal S, Sanders SJ, Murtha MT, et al. Intellectual disability is associated with increased runs of homozygosity in simplex autism. Am J Hum Genet. 2013;93(1):103-9.

30. Kalish JM, Jiang C, Bartolomei MS. Epigenetics and imprinting in human disease. Int J Dev Biol. 2014;58(2-4):291-8. 
31. Peters J. The role of genomic imprinting in biology and disease: an expanding view. Nat Rev Genet. 2014;15(8):517-30.

32. Fan YS, Ouyang X, Peng J, Sacharow S, Tekin M, Barbouth D, et al. Frequent detection of parental consanguinity in children with developmental disorders by a combined CGH and SNP microarray. Mol Cytogenet. 2013;6.

33. McCann JA, Zheng H, Islam A, Goodyer CG, Polychronakos C. Evidence against GRB10 as the gene responsible for Silver-Russell syndrome. Biochem Biophys Res Commun. 2001;286(5):943-8.

34. Bartholdi D, Krajewska-Walasek M, Ounap K, Gaspar H, Chrzanowska KH, Ilyana $\mathrm{H}$, et al. Epigenetic mutations of the imprinted IGF2-H19 domain in Silver-Russell syndrome (SRS): results from a large cohort of patients with SRS and SRS-like phenotypes. J Med Genet. 2009;46(3):192-7.

35. Begemann M, Spengler S, Gogiel M, Grasshoff U, Bonin M, Betz RC, et al. Clinical significance of copy number variations in the 11 p15.5 imprinting control regions: new cases and review of the literature. J Med Genet. 2012:49(9):547-53.

36. Mussa A, Russo S, Larizza L, Riccio A, Ferrero GB. (Epi)genotype-phenotype correlations in Beckwith-Wiedemann syndrome: a paradigm for genomic medicine. Clin Genet. 2015. doi:10.1111/cge.12635.

37. Horsthemke B. Mechanisms of imprint dysregulation. Am J Med Genet C: Semin Med Genet. 2010;154C(3):321-8.

38. Iourov IY, Vorsanova SG, Yurov YB. Chromosomal variation in mammalian neuronal cells: known facts and attractive hypotheses. Int Rev Cytol. 2006;249:143-91.

39. Iourov IY, Vorsanova SG, Yurov YB. Chromosomal mosaicism goes global. Mol Cytogenet. 2008;1:26.

40. Satterlee JS, Beckel-Mitchener A, Little R, Procaccini D, Rutter JL, Lossie AC. Neuroepigenomics: Resources, Obstacles, and Opportunities. Neuroepigenetics. 2015;1:2-13.

41. Iourov IY, Vorsanova SG, Yurov YB. Recent patents on molecular cytogenetics. Recent Pat DNA Gene Seq. 2008;2(1):6-15.

42. Kearney HM, Kearney JB, Conlin LK. Diagnostic implications of excessive homozygosity detected by SNP-based microarrays: consanguinity, uniparental disomy, and recessive single-gene mutations. Clin Lab Med. 2011;31(4):595-613.

43. Kalsner $\mathrm{L}$, Chamberlain SJ. Prader-Willi, Angelman, and 15q11-q13 Duplication Syndromes. Pediatr Clin North Am. 2015;62(3):587-606.

44. Margolis SS, Sell GL, Zbinden MA, Bird LM. Angelman Syndrome Neurotherapeutics. 2015;12(3):641-50.

45. Curtis D. Extended homozygosity is not usually due to cytogenetic abnormality. BMC Genet. 2007;8:67.

46. Iourov IY, Vorsanova SG, Yurov YB. In silico molecular cytogenetics: a bioinformatic approach to prioritization of candidate genes and copy number variations for basic and clinical genome research. Mol Cytogenet. 2014;7:98.

47. Cui H, Dhroso A, Johnson N, Korkin D. The variation game: Cracking complex genetic disorders with NGS and omics data. Methods. 2015;79-80:18-31.

48. lourov IY, Vorsanova SG, Kurinnaaya OS, Kolotii AD, Demidova IA, Kravets VS, et al. The use of molecular cytogenetic and cytogenetic techniques for the diagnosis of Prader-Willi and Angelman syndrome. Zh Nevrol Psikhiatr Im S S Korsakova. 2014;114(1):49-53.

49. Vorsanova SG, Yurov IY, Demidova IA, Voinova-Ulas VY, Kravets VS, Solov'ev IV, et al. Variability in the heterochromatin regions of the chromosomes and chromosomal anomalies in children with autism: identification of genetic markers of autistic spectrum disorders. Neurosci Behav Physiol. 2007;37(6): 553-8.

50. Yurov YB, Vorsanova SG, lourov IY, Demidova IA, Beresheva AK, Kravetz VS, et al. Unexplained autism is frequently associated with low-level mosaic aneuploidy. J Med Genet. 2007:44(8):521-5.

51. lourov IY, Vorsanova SG, Kurinnaia OS, Zelenova MA, Silvanovich AP, Yurov YB. Molecular karyotyping by array CGH in a Russian cohort of children with intellectual disability, autism, epilepsy and congenital anomalies. Mol Cytogenet. 2012;5:46.

52. lourov IY, Vorsanova SG, Voinova VY, Kurinnaia OS, Zelenova MA, Demidova IA, et al. Xq28 (MECP2) microdeletions are common in mutation-negative females with Rett syndrome and cause mild subtypes of the disease. Mol Cytogenet. 2013;6:53.

53. lourov IY, Vorsanova SG, Liehr T, Kolotii AD, Yurov YB. Increased chromosome instability dramatically disrupts neural genome integrity and mediates cerebellar degeneration in the ataxia-telangiectasia brain. Hum Mol Genet. 2009;18(14):2656-69.

\section{Submit your next manuscript to BioMed Central and take full advantage of:}

- Convenient online submission

- Thorough peer review

- No space constraints or color figure charges

- Immediate publication on acceptance

- Inclusion in PubMed, CAS, Scopus and Google Scholar

- Research which is freely available for redistribution

Submit your manuscript at www.biomedcentral.com/submit

C Biomed Central 